\title{
Naar een wettelijke verankering van de maatschappelijke onderneming
}

\author{
Mr. Chr.M. Stokkermans *
}

\begin{abstract}
De recente aanzet van het Ministerie van EZK voor een wettelijke verankering van de maatschappelijke onderneming verdient nog enige aanscherping om er, zonder afbreuk aan het 'gelijk speelveld'-beginsel, een reële bijdrage aan de marktontwikkeling van dergelijke ondernemingen van te maken.
\end{abstract}

\section{Inleiding}

Het Ministerie van Economische Zaken en Klimaat (EZK) heeft onlangs een consultatiedocument naar buiten gebracht, getiteld: 'Aanzet voor een wettelijke regeling voor een besloten vennootschap met een maatschappelijk doel (BVm)'. ${ }^{1}$ Het is in zekere zin pionierswerk, want Nederland kent nog geen wettelijke regeling voor de maatschappelijke onderneming. Dat dit fenomeen nu aandacht van de wetgever krijgt, is een goede zaak.

Ik bespreek dit EZK-voorstel aan de hand van enkele kernelementen. Aan de orde komen: de achtergrond en kern van het voorstel (par. 2), de omschrijving van de doelgroep (par. 3), alsmede de baten die voor ondernemers aan de BVmstatus zijn verbonden (par. 4). Verder wordt aandacht besteed aan beperkingen rond het financieel beleid (par. 5), transparantie en dialoog (par. 6), alsmede aan het handhavingsinstrumentarium (par. 7). Ik ga ten slotte in op de voorgestelde regels over de keuze voor en beëindiging van de BVm-status (par. 8) en eindig met enkele concrete conclusies (par. 9).

Spoiler alert: het idee om de maatschappelijke onderneming met een wettelijke verankering te ondersteunen, onderschrijf ik van harte. De uitwerking kan in mijn optiek beter. Ik hoop dat een wettelijke regeling snel tot stand komt.

Veel mensen hebben wel een globaal beeld van wat een maatschappelijke onderneming is. ${ }^{2}$ Men kan denken aan Fairphone, dat mobiele telefoons verkoopt die gemaakt zijn van eerlijke materialen en vervangbare onderdelen. Of aan Travel Elec-

* Mr. Chr.M. Stokkermans is oud-notaris te Amsterdam.

1. Het voorstel is van 9 maart $\mathrm{t} / \mathrm{m} 30$ april 2021 in consultatie op www.internetconsultatie.nl.

2. De 'maatschappelijke onderneming' wordt ook wel als 'sociale onderneming' aangeduid. Ik gebruik zo consequent mogelijk de eerstgenoemde term. tric (voorheen: Taxi Electric), ${ }^{3}$ dat in Amsterdam uitsluitend met elektrische taxi's rijdt om luchtverontreiniging en geluidsoverlast te beperken en dat actief vijftigplussers als chauffeurs werft. Nog een ander voorbeeld is AutiTalent, dat een passende werkplek probeert te vinden voor mensen uit het autismespectrum. ${ }^{4}$

Globaal gesproken gaat het om ondernemingen waarbij de maatschappelijke missie vooropstaat ('impact first'). Te voorzien in een redelijk inkomen voor de ondernemer is hooguit een randvoorwaarde. Die 'impact first'-doelstelling maakt het verschil ten opzichte van het steeds populairder wordende fenomeen 'maatschappelijk verantwoord ondernemen' (MVO). Bij MVO gaat het om maatschappelijk verantwoord gedrag als randvoorwaarde bij ondernemen. Bij 'gewoon' ondernemen wordt MVO gelukkig meer en meer als een standaard randvoorwaarde gezien; bij maatschappelijk ondernemen geldt dat nog sterker.

Adviesbureau McKinsey schatte dat Nederland in 2016 ongeveer 5000 à 6000 maatschappelijke ondernemingen telde, met grofweg 75.000 medewerkers, die gezamenlijk bijna EUR 3,5 miljard toevoegen aan het bruto nationaal product. Onderzoek van ABN Amro uit 2017 gaat uit van 4000 à 5000 ondernemingen, die 50.000 à 70.000 mensen van werk voorzien. ${ }^{5}$ Maatschappelijke ondernemingen vormen overigens geen vastomlijnde groep. Zo maakt het uit of een dochtermaatschappij binnen een verder niet maatschappelijk ondernemend concern wel of niet in aanmerking kan komen. En of alle medische en zorgondernemers mogen meedoen, inclusief (alle) tandartsen, plastisch chirurgen en verzorgingshuiseigenaren.

3. Getroffen door de coronacrisis ging dit bedrijf begin 2020 failliet, waarna het een snelle doorstart maakte onder een nieuwe naam. Zie www.travelelectric.nl.

4. Voorbeelden ontleend aan de Initiatiefnota 'Ondernemen met een maatschappelijke missie. (H)erkenning van Sociale Ondernemingen door de BVm' van het Kamerlid Bruins (uit 2018) (Kamerstukken II 2018/19, 35040, nr. 2), p. 1 en KPMG \& Nyenrode, Stimuleren van (h)erkenning van sociale ondernemingen (opdrachtgever: EZK), 2020, p. 7.

5. McKinsey \& Company, Scaling the impact of the social enterprise sector, 2016, p. 5; ABN AMRO, De romantiek voorbij: de noodzaak van marktontwikkeling voor sociale ondernemingen, 2017, p. 17. 


\section{Maandblad}

Ondernemingsrecht

\section{Achtergrond en kern van het voorstel}

\subsection{Het RSO, de B Corp en de Europese Unie}

Er lopen allerlei private initiatieven om maatschappelijke ondernemingen een steuntje in de rug te geven door het vergroten van hun zichtbaarheid, het scherp houden van hun maatschappelijke focus en het bijdragen aan professionalisering. In Nederland gebeurt dit onder meer door de Stichting Code Sociale Ondernemingen, opgericht in 2018. Deze stichting houdt een Register Sociale Ondernemingen (RSO). Voor toelating tot het register dient de onderneming de Code Sociale Ondernemingen te onderschrijven. ${ }^{6} \mathrm{Om}$ te waarborgen dat de onderneming daadwerkelijk een maatschappelijke missie vooropstelt, wordt zij voorafgaand aan registratie en geregeld nadien aan een review onderworpen. ${ }^{7}$ Op dit moment staan 32 maatschappelijke ondernemingen in het RSO ingeschreven.

Een ander privaat initiatief is de certificering van ondernemingen tot B Corp. Deze van oorsprong Amerikaanse certificering gaat uit van de non-profitorganisatie B Lab. Wereldwijd zijn ongeveer 3500 bedrijven als B Corp gecertificeerd, waarvan ruim 80 in Nederland. Bijvoorbeeld Triodos Bank N.V. is een B Corp. Net als bij het RSO vinden er beoordelingen plaats om het maatschappelijk gehalte te waarborgen. Voor de B Corp gelden overigens lichtere eisen dan voor het RSO. ${ }^{8}$

In EU-verband is de volgende omschrijving ontwikkeld:

'A social enterprise is an operator in the social economy whose main objective is to have a social impact rather than to make a profit for their owners or shareholders. It operates by providing goods and services for the market in an entrepreneurial and innovative fashion and uses its profits primarily to achieve social objectives. It is managed in an open and responsible manner and, in particular, involves employees, consumers and stakeholders affected by its commercial activities.'

Deze omschrijving wordt onder meer gehanteerd in een Europese verordening die de financiering via 'impact investment funds' beoogt te bevorderen.' Dezelfde elementen komen terug in de Europese Aanbestedingsrichtlijn, waarmee lidstaten worden gestimuleerd om in hun aanbestedingstrajecten voor diensten op het gebied van gezondheid en sociale en culturele diensten ruimte te creëren voor maatschappelijke

6. De Code Sociale Ondernemingen is opgesteld op initiatief van Social Enterprise NL.

7. Zie www.codesocialeondernemingen.nl.

8. Zie www.bcorporation.eu. Zie over de B Corp ook E.R. Helder, Maatschappelijke onderneming en social enterprise, TvOB 2014, afl. 3, p. 93-100 en R.L. Pouwer, B Corp in het Nederlandse vennootschapsrecht anno 2019 nog een storm in een glas water, MvO 2019, afl. 7, p. 185-189.

9. Verordening (EU) 346/2013 inzake Europese sociaalondernemerschapsfondsen. ondernemingen. ${ }^{10}$ Van de 27 lidstaten van de EU plus Zwitserland hebben er 16 wetgeving gericht op de ondersteuning van maatschappelijke ondernemingen. ${ }^{11}$ De verschillen tussen deze regelingen zijn aanzienlijk. ${ }^{12}$

\subsection{Het EZK-voorstel}

De Nederlandse rijksoverheid wil ook een steentje bijdragen. Het nu voorliggende voorstel vloeit voort uit een afspraak uit het regeerakkoord van 2017 en een initiatiefnota van Tweede Kamerlid Eppo Bruins uit 2018. ${ }^{13}$ Er zijn ook diverse onderzoeksrapporten, ${ }^{14}$ een Kamercommissiedebat ${ }^{15}$ en Kamerbrieven ${ }^{16}$ aan het voorstel voorafgegaan. De laatste door EZK bestelde onderzoeksrapporten zijn van KPMG en Nyenrode en van BMC. ${ }^{17}$

Het rapport van KPMG en Nyenrode bespreekt zes verschillende mogelijkheden voor een wettelijke verankering van maatschappelijke ondernemingen. Twee daarvan hebben volgens het rapport de meeste potentie en verdienen nader onderzoek. Ten eerste: een nieuwe rechtsvorm, de BVm. En ten tweede: het wettelijk verankeren van de Code Sociale Ondernemingen (eventueel met toekenning van een wettelijke status ' $\mathrm{BVm}$ '). ${ }^{18}$ Deze varianten scoorden in een survey het hoogst qua acceptatiegraad (is deze oplossing een goed idee?) en qua adoptiegraad (is deze oplossing geschikt voor uw eigen onderneming?). De survey gaf overigens slechts beperkte duidelijkheid over de precieze eigenschappen van de gepresenteerde alternatieven, waardoor de zeggingskracht van het onderzoek beperkt is.

BMC benoemt een vijftal actuele knelpunten voor maatschappelijk ondernemers. Eén, er is verwarring over wat precies onder het begrip 'maatschappelijke onderneming' zou moeten vallen. Twee, hoe men maatschappelijke impact moet meten, is nog niet zo duidelijk. Drie, veel maatschappelijk onderne-

10. Richtlijn 2014/24/EU betreffende het plaatsen van overheidsopdrachten (zie met name art. 77 lid 2).

11. EZK-voorstel 2021, p. 1.

12. A. Argyrou, Social enterprises in the EU. Law promoting stakeholder participation in social enterprises, Deventer: Wolters Kluwer 2018; Europese Commissie, Social enterprises and their ecosystems in Europe. Comparative synthesis report, 2020.

13. Regeerakkoord 'Vertrouwen in de toekomst', 2017, par. 2.4: 'Er komen passende regels en meer ruimte voor ondernemingen met sociale of maatschappelijke doelen met behoud van een gelijk speelveld.' Initiatiefnota Bruins 2018.

14. Social Enterprise NL, Iedereen winst, 2014; SER, Sociale ondernemingen: een verkennend advies, 2015; PWC, De succesfactoren van een sociale onderneming, 2015; OECD/EU, Boosting social entrepreneurship and social enterprise development in the Netherlands (OECD Working Paper), Parijs 2019; Universiteit Utrecht, Versnelling en verbreding van sociaal ondernemerschap (opdrachtgever: EZK), 2019.

15. Verslag van een notaoverleg van 2 december 2019, Kamerstukken II 2019/20, 35040, nr. 12.

16. Kamerbrieven van 17 mei 2019 (Kamerstukken II 2018/19, 32637, nr. 372) en 10 juli 2020 (Kamerstukken II 2019/20, 32637, nr. 426).

17. KPMG \& Nyenrode 2020. BMC, Versterken sociaal ondernemerschap (opdrachtgever: EZK), 2020. De kabinetsreactie op deze rapporten is vervat in de Kamerbrief van 10 juli 2020 (Kamerstukken II 2019/20, 32637, nr. 426).

18. KPMG \& Nyenrode 2020, p. 5 en 50. 
mers lopen aan tegen wet- en regelgeving en administratieve lastendruk. Vier, in sommige categorieën hebben maatschappelijk ondernemers problemen bij het aantrekken van financiering. En vijf, er wordt nog te weinig gedaan aan acceleratieprogramma's gericht op maatschappelijk ondernemers en coaching.

BVm staat voor 'BV met een maatschappelijk doel'. In het EZK-voorstel is gekozen voor een $\mathrm{BVm}$, maar niet als rechtsvorm. De 'BVm' wordt in het voorstel geen modaliteit van de $\mathrm{BV}$, te regelen in Boek $2 \mathrm{BW}$, maar een handelsnaamtechnische faciliteit. Ook is niet gekozen voor een wettelijke verankering van de Code Sociale Ondernemingen. Het voorstel geeft eigen criteria om voor het BVm-label in aanmerking te kunnen komen. Naast inhoudelijke criteria stelt het voorstel eisen aan de statuten van de vennootschap. Verder wordt voorgeschreven dat de keuze voor het BVm-label in een aparte notariële akte wordt vastgelegd, en dat de keuze wordt ingeschreven in het handelsregister. ${ }^{19}$

\section{Omschrijving van de doelgroep}

Het EZK-voorstel lijkt voor de $\mathrm{BVm}$ een ruime en tegelijkertijd smalle doelgroep op het oog te hebben. Men zou die doelgroep kunnen omschrijven als: de ondernemers die voordeel kunnen halen uit de baten die de BVm-status biedt en bereid zijn zich naar de vereisten te voegen. De voorgestelde baten zijn overigens beperkt (zie par. 4.1), al kunnen die oplopen indien bijvoorbeeld impactfinanciers en overheden en anderen die aan 'buy social' willen doen blind op de BVmstatus zouden gaan vertrouwen. De voorgestelde vereisten zijn betrekkelijk licht (zie par. 5 en 6). Een duidelijk kwantitatief en kwalitatief beeld van de doelgroep waarop de regeling gericht is, ontbreekt in het EZK-voorstel.

\subsection{Alleen voor de $B V$ ?}

Een beperking qua doelgroep ligt erin besloten dat alleen een $\mathrm{BV}$ (besloten vennootschap) de BVm-status kan krijgen. De door het ministerie opgevoerde argumenten voor deze beperking zijn niet sterk. Zo wordt over de naamloze vennootschap (NV) gesteld dat die rechtsvorm niet geschikt is voor een maatschappelijke onderneming, aangezien haar aandelen vrij verhandelbaar zijn. ${ }^{20}$ Dit miskent dat zowel bij de NV als bij de BV de overdracht van aandelen statutair beperkt of onbeperkt kan zijn. ${ }^{21}$ Bovendien staat een vrije verhandelbaarheid van aandelen niet aan het statutair borgen van een maatschappelijke missie in de weg. ${ }^{22}$ Het voorstel sluit vrije verhandelbaarheid of zelfs beursnotering voor de BVm ook niet uit.

Ook de geschiktheid van de coöperatie als rechtsvorm voor maatschappelijke ondernemingen wordt in het EZK-voorstel

19. EZK-voorstel 2021, p. 2-5.

20. EZK-voorstel 2021, p. 4.

21. Art. 2:87 en 2:195 BW; er zijn ook beursgenoteerde BV's.

22. Zie over de maatschappelijke onderneming in NV-vorm ook R.J.C. van Helden, Reactie, WPNR 2020, afl. 7308, p. 961-963. onnodig in twijfel getrokken. ${ }^{23}$ Een op buurtzorg gerichte maatschappelijke onderneming kan bijvoorbeeld uitstekend in de vorm van een werknemerscoöperatie worden gegoten. Het genereren van een bescheiden inkomen voor de werknemersleden kan daarbij als nevendoel (randvoorwaarde) gelden. Artikel 2:53 lid $1 \mathrm{BW}$ vereist niet dat het voorzien 'in bepaalde stoffelijke behoeften' van de leden het hoofddoel van de coöperatie moet zijn; het 'impact first'-idee kan op een ander doel zijn gericht, zoals buurtzorg. In veel landen, waaronder België, ${ }^{24}$ ziet men de coöperatie zelfs als de rechtsvorm voor maatschappelijke ondernemingen bij uitstek. ${ }^{25}$ Ook de geschiktheid van vereniging en stichting als rechtsvorm voor maatschappelijk ondernemen wordt in het voorstel ten onrechte ter discussie gesteld. Een bestaande en juridisch zuivere praktijk wordt hiermee tekortgedaan.

Maatschappelijke ondernemingen die om uiteenlopende redenen een andere rechtsvorm hebben dan de BV worden in het voorstel van de wettelijke 'm'-status uitgesloten. ${ }^{26}$ Dit betekent nogal wat, want dit treft een flink aantal maatschappelijke ondernemingen. Naast de BV worden met name de rechtsvormen stichting, vereniging, coöperatie en NV geregeld gebruikt. $^{27}$ Is het echt nodig om deze groep van wettelijke erkenning uit te sluiten of tot omzetting in een BV te dwingen?

In het voorstel is de BVm een gewone BV in de zin van Boek 2 $\mathrm{BW}$. De statutaire naam van een dergelijke vennootschap is gewoon 'xyz B.V.' Aan de regel dat uit alle geschriften, gedrukte stukken en aankondigingen van de vennootschap (met uitzondering van telegrammen en reclames) deze statutaire naam moet blijken, ${ }^{28}$ doet het EZK-voorstel niets af. De voorgestelde $\mathrm{BVm}$-status is slechts een faciliteit in de sfeer van de handelsnaam. Handelsnaamtechnisch mag xyz B.V. zich 'xyz BVm' noemen, indien zij de BVm-status heeft verworven. ${ }^{29}$

In de gekozen oplossing is $\mathrm{BVm}$ een wettelijk label. Als men voor een label kiest, waarom dan geen multirechtsvorm- (en handelsnaamneutraal) label? Bij wet kan bijvoorbeeld worden geregeld dat bepaalde typen rechtspersonen die aan specifieke

23. EZK-voorstel 2021, p. 3 onderaan.

24. In België kan sinds 1 mei 2019 alleen de coöperatieve vennootschap (met bepaalde bijzondere regelingen) nog de status 'sociale onderneming' ( $\mathrm{SO}$ ) krijgen. Zie art. 8.4 en 8.5 van het (Belgische) Wetboek van vennootschappen en verenigingen en art. 6 e.v. KB van 28 juni 2019 tot vaststelling van de voorwaarden van de erkenning als landbouwonderneming en als sociale onderneming, BS 11 juli 2019.

25. Voor een Europees overzicht, zie T. Lambooy, A. Argyrou \& A. Bolhuis, A tailor-made legal form for social enterprises in the Netherlands is on its way, European Company Law Journal (18) 2021, afl. 1, p. 27.

26. Vgl. het in 2013 ingetrokken wetsvoorstel uit 2009 dat juist ging over maatschappelijke ondernemingen in de rechtsvorm van een vereniging en stichting. Kamerstukken 32003.

27. Vgl. M.J.L.A.M. Zillikens-Loos e.a., De maatschappelijke onderneming en haar (nieuwe) juridische jas, MvO 2020, afl. 8/9, p. 251-252; deze auteurs bepleiten naast de BVm een stichting- $m$ en een coöperatie- $m$.

28. Art. 2:177 en 2:186 BW.

29. EZK-voorstel 2021, p. 5. 


\section{Maandblad}

Ondernemingsrecht

vereisten voldoen, in een aan het handelsregister gekoppeld register worden ingeschreven met het predicaat 'erkende maatschappelijke onderneming' (EMO).

\subsection{Het anbi-sectorenlijstje}

Daarnaast is de vraag: hoe streng zijn de vereisten rond doel en werkzaamheid die het voorstel aan het verkrijgen van de BVmstatus stelt? De BVm is verplicht 'met haar werkzaamheden een in de statuten omschreven doel van maatschappelijk belang na te streven of te bevorderen'. De statuten van de $\mathrm{BVm}$ moeten verder 'een omschreven voorwerp van werkzaamheid [bevatten] dat in overeenstemming is met het doel van maatschappelijk belang'. Als 'maatschappelijk belang' worden beschouwd de sectoren: welzijn, cultuur, bescherming van natuur en milieu (inclusief bevordering van duurzaamheid), gezondheidszorg, arbeidsmarktparticipatie en nog een aantal limitatief opgesomde terreinen. ${ }^{30}$ Gezien dit lijstje lijken het notariaat en de (sociale) advocatuur van de BVm te worden uitgesloten. Waarom eigenlijk? ?1 $^{31}$

Voor het sectorenlijstje van 'maatschappelijk belang' is aansluiting gezocht bij de fiscale regeling voor algemeen nut beogende instellingen (anbi's) in artikel 5b Algemene wet inzake rijksbelastingen (AWR). ${ }^{32}$ Het voordeel van de anbistatus is vooral dat schenkingen aan en door een anbi fiscaal gefaciliteerd zijn. In de praktijk gaat het hoofdzakelijk om goededoelenstichtingen. Het is niet uitgesloten dat de anbi een onderneming drijft, maar enkele rechtsvormen, waaronder NV, BV en coöperatie, zijn sinds 2012 van de anbi-status uitgesloten. Het EZK-voorstel sluit bij het anbi-sectorenlijstje aan om te waarborgen dat de BVm daadwerkelijk in het maatschappelijk belang zal opereren.

Het voorstel lijkt ervan uit te gaan dat men voor de BVmstatus slechts hoeft vast te stellen dat doel en werkzaamheden van de vennootschap binnen het anbi-sectorenlijstje passen. Dit maakt het bereik van de BVm zodanig ruim dat er veel meer ondernemingen onder kunnen gaan vallen dan de eerdergenoemde 4000 à 6000 .

Voor de anbi-status (art. 5b AWR) moet de instelling niet alleen binnen het sectorenlijstje opereren (lid 3), maar qua formeel doel en feitelijke gerichtheid ook daadwerkelijk op een maatschappelijk belang zijn gericht (lid 1). Of aan dat laatste wordt voldaan, wordt onder meer bepaald door de eis dat ten minste $90 \%$ van de activiteiten voor een publiek belang en dus niet een particulier belang wordt ondernomen. Een aan de jurisprudentie ontleend voorbeeld dat de reikwijdte van lid 1 illustreert, gaat over een organisator van rhythm-and-bluesfestivals. De activiteiten vielen weliswaar binnen het sectorenlijstje (cultuur), maar in het concrete geval stond volgens het hof 'een ontmoeting tussen publiek en artiesten en het bieden

30. EZK-voorstel 2021, p. 6-7.

31. Ik wierp deze vraag eerder al op in Chr.M. Stokkermans, Het notariaat en de grand bargain, WPNR 2021, afl. 7321, p. 316.

32. EZK-voorstel 2021, p. 7-10. van het bijbehorende kader' op de voorgrond. Volgens het hof was dit een beperkt belang en daarmee geen algemeen belang; de Hoge Raad onderschreef dit. ${ }^{33}$

Het sectorenlijstje is volgens mij onvoldoende om voor de maatschappelijke onderneming tot een goede selectie van doel en werkzaamheden te komen. De vraag hoe deze in de BVmregeling het best kunnen worden ingekleurd, is niet eenvoudig. Een formele, precies afgebakende regeling zonder individuele beoordeling zal snel te krap zijn (waardoor te veel maatschappelijk ondernemers buiten de boot vallen), of juist te ruim (met een hoog risico op 'groenwassen'). Dit laatste is vrees ik aan de orde als geen nadere eisen aan doel en feitelijke werkzaamheden worden gesteld.

In het EZK-voorstel valt verder op dat twee sectoren aan het anbi-lijstje zijn toegevoegd (mensenrechten en arbeidsparticipatie). Ik vind dat ongelukkig, omdat die twee sectoren blijkens jurisprudentie al onder bestaande categorieën uit het anbi-lijstje vallen. Zo valt onder de categorie 'welzijn', volgens gerechtshof Amsterdam: het bevorderen van de aansluiting op de arbeidsmarkt van personen die deze verliezen of dreigen te verliezen. ${ }^{34} \mathrm{Ik}$ wijs ook op uitlatingen van de Staatssecretaris van Financiën, die Amnesty International als voorbeeld van de categorie 'bevordering van de democratische rechtsorde' noemde, ${ }^{35}$ en het bevorderen van het welzijn van kwetsbare groepen in de categorie 'welzijn' plaatste. ${ }^{36}$ Een eenvormige categorisering zou verwarring voorkomen en verdient daarom de voorkeur.

\subsection{Uitdagender toets?}

Het kan anders. Zo geldt voor opneming in het RSO geen formeel, strak afgebakend vereiste, maar een inhoudelijke, uitdagende toets (met een daaraan gekoppelde individuele beoordeling). Voor toelating tot het RSO moet de onderneming zich bezighouden met een of meer van de volgende impactgebieden: verhoging van arbeidsparticipatie van een kwetsbare doelgroep, verbetering van de zorg, het verhogen van sociale cohesie in wijken en buurten, circulaire en duurzame productie, energietransitie, voedseltransitie en duurzame internationale productieketen (fair chain). ${ }^{37}$ Dit rijtje is uitdagender dan het sectorenlijstje uit het EZK-voorstel. Het straalt uit dat het om een maatschappelijke voorhoede gaat.

Iets van deze ambitie zou ik in de BVm-criteria willen terugzien. De maatschappelijk ondernemer stopt niet bij een sector, maar gaat verder. Dat in de Kamerbrief van 10 juli 2020 wordt gesteld dat een wettelijke status voor de maatschappelijke onderneming op basis van het RSO (en soortgelijke codes) 'zo

33. HR 22 juni 2012, ECLI:NL:HR:2012:BR6294.

34. Hof Amsterdam 13 september 2016, ECLI:NL:GHAMS:2016:4372, NTFR 2017/624.

35. Kamerstukken II 2011/12, 33006, nr. 3, p. 26.

36. Zie onder meer zijn brief van 20 februari 2020, nr. 2020Z00551, NTFR 2020/588 (antwoord op vraag 26).

37. Toelatingscriteria RSO (versie 6 februari 2020), onder 'Grondslag Impact First'. 
algemeen wordt dat die geen betekenis heeft', ${ }^{38}$ kan ik niet plaatsen. De stelling in dezelfde Kamerbrief dat de 'gelijk speelveld'-gedachte ertoe zou dwingen naast het RSO ook soortgelijke codes in de erkenning te betrekken, vind ik evenmin overtuigend. De overheid kan het RSO best als enige een publiekrechtelijke status geven. Ik zeg niet dat het moet, maar wijs op de zwakke onderbouwing in het voorstel.

\section{Baten van de BVm-status}

\subsection{Erkenning en herkenning}

Uit meerdere onderzoeken komt naar voren dat maatschappelijke ondernemingen een gebrek aan erkenning en herkenning ervaren. Daar wil het voorstel iets aan doen. ${ }^{39}$ Concrete voorbeelden: impactfondsen en andere financiers willen graag in maatschappelijke ondernemingen investeren en overheden en private partijen willen hun steentje bijdragen door maatschappelijke ondernemingen een streepje voor te geven bij de inkoop en het uitzetten van opdrachten. Maar zij ontberen de menskracht om, ieder voor zich, individuele ondernemingen op hun daadwerkelijke maatschappelijke bijdrage te beoordelen. Een label waarop zij kunnen afgaan, zou dus wel helpen. Door het groenwasrisico dat in het EZK-voorstel besloten ligt, lijkt de voorgestelde BVm-status niet aan deze vraag te voldoen. Investeerders en gemeenten die het goed willen doen, zullen alsnog tot (vergaande) individuele screening moeten overgaan. Door de voorgestelde regeling iets aan te scherpen kan de wetgever dit vermijden.

Gemakzuchtige ondernemers, financiers en opdrachtgevers zouden het formeel voornamere (want wettelijke) BVm-label kunnen verkiezen boven private, maar veeleisender labels. De vraag rijst of men de echte maatschappelijk ondernemers en het algemeen belang daarmee een dienst bewijst.

Bij het formuleren van en toetsen aan toekenningscriteria zou mijns inziens ook moeten worden betrokken dat 'de maatschappelijke onderneming' geen statisch begrip is. De voorhoede van vandaag is niet per se ook de voorhoede van morgen. Bovendien wordt voortschrijdend gewerkt aan best practices en steeds betere criteria voor impactmeting. Dit vraagt om centrale informatievergaring en regelgeving die een 'levende' ontwikkeling ondersteunt.

Het EZK-voorstel laat de toekenning van de BVm-status aan notarissen over, maar miskent dat een toekenningsbeleid gevoerd zal moeten worden, dat zo nodig (op basis van evaluaties) af en toe kan worden bijgesteld. Zo gaat het ook bij de anbi-status (die door het Ministerie van Financiën wordt toegekend). Dit kan men niet volledig aan individuele notarissen overlaten. Het vraagt om een centrale aansturing. EZK kan dit zelf oppakken, in eigen beheer binnen de Rijksdienst voor Ondernemend Nederland, of er bijvoorbeeld voor kiezen de

38. Kamerbrief 10 juli 2020 (Kamerstukken II 2019/20, 32637, nr. 426), p. 3 .

39. EZK-voorstel 2021, p. 1-2. Zie ook Initiatiefnota Bruins 2018, p. 5.
Stichting Code Sociale Ondernemingen publiekrechtelijk in te bedden.

Een aanpak met een centraal georganiseerde individuele beoordeling (die overigens niet zwaar hoeft te zijn) is ook gekozen voor de Community Interest Company (CIC) in Engeland en voor de sociale onderneming in België. De individuele beoordeling wordt daar overgelaten aan een publieke CIC Regulator, ${ }^{40}$ respectievelijk het Belgische ministerie van Economie (FOD Economie). ${ }^{41}$

Verder kan de overheid, ongeacht of voor het wettelijke mlabel bij het private initiatief wordt aangesloten, aan dat private initiatief een steuntje in de rug geven. Zo zou de overheid met een bescheiden financiering voor de Stichting Code Sociale Ondernemingen over de brug kunnen komen. Op dit moment ontvangt de Stichting Code Sociale Ondernemingen geen enkele subsidie. Ter vergelijking: de stichting Centraal Bureau Fondsenwerving, die het voor goede doelen zo belangrijke CBF-keurmerk toekent, ${ }^{42}$ deed het in 2019 met een overheidssubsidie van EUR 323.911. ${ }^{43}$ Die stichting biedt veel waar voor weinig geld.

\subsection{Fiscale en juridische faciliteiten?}

De overheid hamert op de noodzaak van een gelijk speelveld. ${ }^{44}$ De wetgever mag maatschappelijke ondernemingen niet ongerechtvaardigd bevoordelen boven gewone ondernemingen. Het EZK-voorstel heeft daarom slechts ten doel de (h)erkenning van maatschappelijke ondernemingen te helpen bevorderen.

Het is uitdrukkelijk niet de bedoeling van het voorstel om maatschappelijke ondernemingen te helpen met fiscale voordelen. ${ }^{45}$ Enige terughoudendheid begrijp ik, maar het maken van een gerechtvaardigd onderscheid is toch niet verkeerd. Zo kan een stichting of vereniging met een maatschappelijke onderneming de anbi-status hebben en daardoor profiteren van een fiscaal gunstige regeling rond giften. Ik kan me voorstellen dat men de anbi-status ook voor alle wettelijk erkende maatschappelijke ondernemingen beschikbaar maakt. Daarbij kan het fiscale recht voor de anbi-status aanvullende eisen stellen ten opzichte van de BVm-voorschriften. Voor maatschappelijk ondernemers die tegen de verdrukking in aan innovatieve commerciële plannen werken en daarvoor sponsors en subsidiegevers weten te interesseren, kan dit een uitkomst zijn. Waarom zulke ondernemers in het keurslijf van

40. Zie T. Lambooy, P. Anthoni \& A. Argyrou, Aren't we all pursuing societal goals in our businesses? Defining 'societal purpose' as pursued by social enterprises, Sustainable Development 2020, par. 3.

41. Art. 6 e.v. KB van 28 juni 2019 tot vaststelling van de voorwaarden van de erkenning als landbouwonderneming en als sociale onderneming, BS 11 juli 2019.

42. Zie www.cbf.nl.

43. CBF-jaarverslag 2019, p. 45.

44. Reeds uitdrukkelijk: Regeerakkoord 2017, par. 2.4.

45. EZK-voorstel 2021, p. 1 en 26. 
een stichting of vereniging moeten worden gedwongen, is onduidelijk.

Zonder strijd met het 'gelijk speelveld'-principe zouden ook bepaalde juridische faciliteiten kunnen worden gecreëerd. Zo zou het een BV met m-label kunnen worden toegestaan om te kiezen voor een statutaire inrichting die voor gewone BV's verboden is.

Langs deze weg kan bijvoorbeeld steward ownership meer ruimte krijgen. Als de twee kenmerken van steward ownership van vennootschappen worden genoemd: (1) een vorm van zelfbestuur; en (2) de regel dat gerealiseerde winsten hoofdzakelijk voor de missie van de vennootschap worden ingezet. ${ }^{46}$ Vaak wordt dit gerealiseerd door de aandelen van de vennootschap in een stichting onder te brengen. Als alternatief zou Boek 2 BW kunnen toelaten, naast de mogelijkheid alle aandelen slechts beperkt winstdelend te maken (zie par. 5.2), dat de bevoegdheid tot benoeming en ontslag van de bestuurders en commissarissen van een BV met m-label niet per se bij de aandeelhouders berust. ${ }^{47}$ Binnen een dergelijke BV kunnen deze bevoegdheden dan bijvoorbeeld bij een raad van commissarissen worden belegd.

Boek 2 BW zou ook kunnen toestaan dat de statuten van een BV met m-label een verbod op statutenwijziging bevatten, om de maatschappelijke missie te waarborgen. ${ }^{48}$ Het zou ook goed zijn als de maatschappelijke BV de mogelijkheid krijgt om bij of krachtens de statuten bepaalde bestuursbesluiten te onderwerpen aan de goedkeuring van een 'maatschappelijke raad' waarin stakeholders vertegenwoordigd zijn. $\mathrm{Nu}$ kan dat niet, omdat Boek 2 BW de maatschappelijke raad niet als vennootschapsorgaan erkent. ${ }^{49}$

Kortom: wil de wetgever de maatschappelijke onderneming echt een steuntje in de rug geven, dan kan hij, wellicht in samenwerking met private partijen, een ambitieuzere regeling optuigen dan nu wordt voorgesteld. Gezien het belang van de zaak zou ik dat ook wenselijk vinden. Hiervoor is goede samenwerking tussen EZK, het Ministerie van Financiën en het Ministerie van Justitie en Veiligheid nodig.

Het vormgeven van dergelijke fiscale en juridische faciliteiten zou mijns inziens aan de - op korte termijn gewenste invoering van een wettelijk m-label niet in de weg mogen staan. Overwogen kan worden deze punten alvast te agende-

46. Zie bijv. www.purpose-economy.org/en/whats-steward-ownership. Voor voorbeelden in Nederland, zie www.wearestewards.nl.

47. Bij een BV liggen die bevoegdheden dwingend bij aandeelhouders (art. 2:242 en 2:244 BW); het structuurregime (art. 2:262 e.v. BW) laat ik onbesproken.

48. Deze laatste suggestie is gedaan door M.J. van Uchelen-Schipper, Sociale ondernemingen in Nederland: is het BV-recht nog flexibel genoeg?, WPNR 2020, afl. 7298, p. 713-726. In dat geval kan statutenwijziging alsnog met toestemming van de rechter mogelijk zijn. Vgl. voor de stichting: art. 2:294 BW.

49. Art. 2:239 lid 3 jo. art. 2:189a BW. Hetzelfde geldt voor de ondernemingsraad. ren voor een vijf jaar na invoering te organiseren evaluatie van de nieuwe wet. Fiscalisten en juristen kunnen dit dan intussen verder uitdenken.

\section{Financieel beleid}

Voor ondernemers die de aantrekkelijkheid van het BVmlabel onderzoeken, is uiteraard van belang welke lasten aan de BVm-status vastzitten. In deze sfeer kan men denken aan transparantievoorschriften, het handhavingsinstrumentarium en de mogelijkheden voor beëindiging van de BVm-status. Hierover zo dadelijk. Ook de beperkingen voor het financiële beleid zijn belangrijk.

\subsection{Uitkeringen en het bredere plaatje}

Het EZK-voorstel geeft ruim aandacht aan de mogelijkheden tot het doen van winstuitkeringen. Uitkeringen beperken de slagkracht van de vennootschap voor het nastreven van haar maatschappelijke missie. Er is niet gekozen voor een formule waarin ten hoogste een bepaald percentage van de winst mag worden uitgekeerd (bijvoorbeeld 25 of $50 \%$ ), want dat vond men te instrumenteel, te gedetailleerd en te kwetsbaar voor omzeiling. In plaats daarvan geeft het EZK-voorstel aan bestuurders en aandeelhouders veel vrijheid om eigen afwegingen te maken. De BVm is in het voorstel verplicht 'het maatschappelijk doel voorop te stellen bij het bestemmen van de winst en het doen van uitkeringen', 'voor zover dat redelijkerwijs mogelijk is en naar vermogen'. Bij een uitkering geldt als voorwaarde dat deze 'de instandhouding en de langetermijnbelangen van de aan de vennootschap verbonden onderneming niet in gevaar brengt'. ${ }^{50}$ Het betrekken van een '(veel) te' dure lening bij de bestuurder/enig aandeelhouder wordt als ongepaste omzeiling gezien. ${ }^{51}$ Verder dient de BVm een 'maatschappelijk winst- en reservebeleid' vast te stellen. ${ }^{52}$ Als ik het goed begrijp, wordt een winstbestemmings- en reservebeleid bedoeld.

De gedachte dat de maatschappelijke missie van de vennootschap niet eenvoudigweg met een verbod op uitkeringen boven een bepaald percentage van de winst geborgd kan worden, deel ik. Toch lijkt het normatieve kader van het EZKvoorstel onvoldoende. Bij maatschappelijk ondernemen zal men niet zo snel denken in termen van uitkeringen als percentage van de winst, maar veeleer in uitkeringen als percentage van verschaft kapitaal. ${ }^{53}$ Wil men voldoende kapitaal kunnen aantrekken, dan zal men doorgaans een redelijk rendement op dat kapitaal in het vooruitzicht moeten stellen, ook als dat een groot deel van de winst opsoupeert. Daarentegen kunnen winstuitkeringen die een redelijk rendement te

50. EZK-voorstel 2021, p. 2, 10 en 11.

51. EZK-voorstel 2021, p. 13.

52. EZK-voorstel 2021, p. 15.

53. Vgl. art. 6 sub 7 van het Belgische KB van 28 juni 2019, dat uitkeringen maximeert op een percentage van het gestorte kapitaal. Ook deze eendimensionale maatstaf is ontoereikend, want geeft een te laag rendement bij hoog risico (of andersom). Hierdoor worden investeringen met hoog risico ontmoedigd (of kunnen investeringen met laag risico te hoog worden beloond). 
boven gaan al bij een laag percentage van de winst excessief zijn.

Daarnaast verdient het hele financiële beleid aandacht, niet slechts het winst- en reservebeleid. Zo zal het vaak passend zijn om niet naar winstmaximalisatie te streven, maar veeleer naar bescheiden prijzen voor de te leveren goederen of diensten. Een gematigd beloningsbeleid lijkt eveneens gewenst. Wel moeten bestuurders/aandeelhouders ook op een verzorgde oude dag kunnen sturen, bijvoorbeeld door, bij verkoop rond de pensioenleeftijd, opgebouwde goodwill geheel of ten dele te verzilveren.

Het EZK-voorstel staat aan dit bredere plaatje niet in de weg, maar is mijns inziens te vaag op dit punt. De benadering die ik bedoel, komt scherper en beter naar voren in de toelatingscriteria van het RSO. Die verlangen dat de onderneming voortdurend een zorgvuldige afweging maakt tussen herinvesteren en een redelijke vergoeding voor aandeelhouders, gemotiveerd uitlegt hoe de impact in het financieel beleid is geborgd, en een gematigd beloningsbeleid voert. ${ }^{54}$

De statuten moeten volgens het EZK-voorstel inhouden dat een batig liquidatiesaldo na ontbinding van de vennootschap wordt bestemd voor een andere $\mathrm{BVm}$ of voor een andere rechtspersoon die een ideëel of sociaal doel nastreeft. ${ }^{.5}$ Dit is volgens mij een goede bepaling. Wel is de reikwijdte ervan beperkt, want de regeling staat niet in de weg aan uitkeringen aan andersoortige partijen, waaronder aandeelhouders, die (vlak) voorafgaand aan de ontbinding worden gedaan.

\subsection{Governance rond uitkeringen}

In het EZK-voorstel wordt het winst- en reservebeleid vastgesteld door de algemene vergadering (tenzij de statuten hiervoor een ander orgaan aanwijzen) op een voorstel van het bestuur. Tot het doen van concrete uitkeringen (al dan niet in afwijking van het vastgestelde beleid) besluit de algemene vergadering; het bestuur mag geen uitkeringen toestaan indien het 'meer dan gerede twijfel' heeft 'dat die uitkering de BVm belemmert het maatschappelijk doel voorop te stellen'. ${ }^{56}$ Dit zal bedoeld zijn als een minimumbevoegdheid voor het bestuur. De statuten zullen aan het bestuur een ruimere weigerbevoegdheid kunnen toekennen, of zelfs de hele uitkeringsbevoegdheid aan het bestuur kunnen overlaten. ${ }^{57}$

Op zich zijn dit goede regels. Wel kan de weigergrond, 'meer dan gerede twijfel (etc.)', mijns inziens beter worden vervangen door de algemene maatstaf die de wet voor het weigeren van statutair toegelaten instructies aan het bestuur hanteert

54. RSO-toelatingscriteria (versie 6 februari 2020), onder 'Principe 3: Financiën - in overleg en zorgvuldig afgewogen'.

55. EZK-voorstel 2021, p. 25.

56. EZK-voorstel 2021, p. 14-15.

57. De algemene goedkeuringsbevoegdheid van het bestuur bij uitkeringen (art. 2:216 lid 2 BW), die volgens het EZK-voorstel ook voor de BVm zal gelden, laat die ruimte eveneens. Zie Asser/Van Olffen \& Rensen 2-IIa 2019/208, sub g. ('tenzij deze in strijd zijn met het belang van de vennootschap en de met haar verbonden onderneming'). ${ }^{58} \mathrm{Bij}$ de $\mathrm{BVm}$ is het maatschappelijk doel ('impact first') immers sterk in het belang van de vennootschap verankerd. Voor de invulling van de genoemde algemene maatstaf kan men een prominente plaats geven aan het 'impact first'-beginsel en een matigheidsnorm hanteren. Door aldus aan te sluiten bij bestaande open normen wordt het beoordelingskader niet nodeloos ingewikkeld gemaakt en geeft men het bestuur een eigen volwassen verantwoordelijkheid. Het voorgestelde 'meer dan gerede twijfel' drukt het bestuur mijns inziens te veel in de verdediging.

Een andere vraag is nog in hoeverre winstrechten van aandeelhouders beperkt of uitgesloten kunnen worden. Volgens het EZK-voorstel dient een zeker winstrecht van aandeelhouders gewaarborgd te blijven. 'Het winstrecht wordt immers in zijn algemeenheid als "wezenlijk onderdeel van het aandeelhouderschap" erkend', zo wordt gesteld. ${ }^{59}$ Dit is volgens mij onjuist. Artikel 2:216 lid 7 BW staat een statutaire regeling toe waarin de aandelen van een soort of aanduiding niet of slechts beperkt in de winst delen. Het is mijns inziens niet verboden dit voor alle aandelen zo te regelen. Wat dit betreft is er voor winstrechtloze aandelen meer flexibiliteit dan voor stemrechtlo$z e$ aandelen. ${ }^{60}$ Wordt toegelaten dat een $\mathrm{BV}$ met m-label tevens anbi kan zijn, dan kan daarbij als voorwaarde worden gesteld dat uitkeringen op aandelen zijn uitgesloten, tenzij de aandeelhouder eveneens een anbi is. Een statutair beperkt winstrecht voor alle aandelen kan voor een BV met m-label in meer gevallen een interessante optie zijn. Zo'n regeling maakt de BV een beetje van zichzelf. Zij kan helpen voorkomen dat bij verkoop van de aandelen een te groot bedrag aan goodwill wordt betaald en de koper vervolgens druk uitoefent op de vennootschap om hem een rendement op de betaalde koopprijs te bezorgen.

\section{Transparantie en dialoog}

Een BV met m-label laat zich op haar maatschappelijke missie voorstaan. Hierbij passen transparantieverplichtingen om derden in staat te stellen na te gaan of de vennootschap aan de gewekte verwachtingen beantwoordt. Derden zoals (potentiële) klanten, toeleveranciers, financiers en werknemers zullen hun verhouding tot de vennootschap op die verwachtingen afstemmen. Voldoende transparantie zal uiteenlopende partijen ook in staat stellen zichzelf en de BVm scherp te houden door goede plannen en resultaten te erkennen, en door de BVm aan te spreken op wat niét goed gaat. Goede en toegankelijke informatie is tevens belangrijk voor (wetenschappelijk) onderzoek en bij de voorbereiding van toekomstig overheidsbeleid.

58. Art. 2:239 lid 4 BW. Deze wetsbepaling geldt niet bij uitkeringen door een gewone BV; zie B.F. Assink, Slagter. Compendium ondernemingsrecht, Deventer: Kluwer 2013, par. 33, p. 590-591.

59. EZK-voorstel 2021, p. 7.

60. Stemrechtloze aandelen zijn toegelaten ingevolge art. 2:228 lid $5 \mathrm{BW}$. Er moet ten minste één aandeel mét stemrecht zijn (art. 2:175 lid 1, laatste volzin, BW; zie ook Kamerstukken II 2006/07, 31058, nr. 3, p. 37). 


\section{Maandblad}

Ondernemingsrecht

\subsection{Publicatieverplichtingen en verslaglegging}

Bij transparantievoorschriften valt in de eerste plaats aan publicatieverplichtingen te denken. De BVm zal om te beginnen de algemene publicatievoorschriften voor BV's in acht moeten nemen. Dit omvat het registreren en deponeren van informatie bij het handelsregister, inclusief statuten en jaarstukken. Volgens het EZK-voorstel dienen de statuten van de BVm een 'doel van maatschappelijk belang' te bevatten en een met dat doel overeenstemmend 'voorwerp van werkzaamheid'. De keuze voor de BVm-status wordt in een aparte notariële akte vastgelegd. Ik leid uit het voorstel af dat dit een kort formeel document kan zijn. Na het opmaken van deze akte wordt de vennootschap als $\mathrm{BVm}$ in het handelsregister ingeschreven. ${ }^{61}$

Daarnaast moet het bestuur van de BVm na afloop van elk boekjaar een maatschappelijk jaarverslag opstellen en openbaar maken, aldus het voorstel. Micro- en kleine BV's hoeven op grond van Boek $2 \mathrm{BW}$ geen bestuursverslag te publiceren en moeten het maatschappelijk jaarverslag daarom (voor zeven jaar) langs elektronische weg openbaar toegankelijk maken. Grote en middelgrote vennootschappen kunnen het maatschappelijk jaarverslag opnemen in het bestuursverslag dat zij op grond van Boek $2 \mathrm{BW}$ toch al openbaar moeten maken. Wat er precies in het maatschappelijk jaarverslag moet komen te staan, is nog niet helemaal uitgewerkt. In elk geval zullen het doel, de werkzaamheid en de met die werkzaamheid gerealiseerde maatschappelijke waarde moeten worden vermeld. Ook het winst- en reservebeleid wordt onder de publicatieverplichting gebracht. ${ }^{62}$ De verslaglegging hoeft volgens het voorstel niet kwantitatief van aard te zijn, maar kan zich beperken tot een kwalitatieve beoordeling. Er zullen geen specifieke kwaliteitseisen voor de verslaglegging gaan gelden. ${ }^{63}$

De kennelijke gedachte hierachter, dat maatschappelijke ondernemingen geen onnodige administratieve lasten voor de kiezen moeten krijgen, deel ik. Het geschetste transparantiepakket komt mij niettemin te mager voor. Wil men een flink maatschappelijk prestatieniveau bevorderen en er geen 'excuuswetgeving' van maken, dan is goede publieke informatievoorziening onontbeerlijk. Dit betreft allereerst de (eenvoudige) vindbaarheid en vergelijkbaarheid van de openbaar te maken gegevens. Op dit punt is mijns inziens gewenst dat alle relevante informatie overzichtelijk op de website van de maatschappelijke onderneming komt te staan, en dat een gratis toegankelijk m-register wordt georganiseerd waar men eenvoudig naar de websites van de geregistreerde ondernemingen kan doorklikken. Het RSO kent een dergelijke structuur.

Voor de inhoud van de openbaar te maken informatie kan eveneens een voorbeeld worden genomen aan het RSO.

61. EZK-voorstel 2021, p. 3-6.

62. Het EZK-voorstel verklaart op p. 15 (nr. 12) stellig dat het winst- en reservebeleid openbaar moet worden; op p. 17 (nr. 14) lijkt men een slag om de arm te houden.

63. EZK-voorstel 2021, p. 17-18.
Daarin opgenomen maatschappelijke ondernemingen zijn verplicht om op hun website publiekelijk toegankelijk te maken: hun missie, visie en strategie, hun statuten, hun stakeholderbeleid, een jaarlijkse impactrapportage, het financieel en beloningsbeleid, de wettelijk verplichte jaarstukken en gegevens over hun governance en zeggenschap. ${ }^{64}$ Aan verschillende van deze elementen worden bij het RSO nadere eisen gesteld.

\subsection{Dialoog}

$\mathrm{Bij}$ het RSO bevordert men tevens een dialoog met stakeholders. In de besproken EU-omschrijving van de maatschappelijke onderneming komt het streven naar dialoog eveneens terug (zie par. 2.1). In het EZK-voorstel ontbreekt dat. De RSO-toelatingscriteria schrijven voor dat de onderneming haar meest relevante stakeholders in kaart brengt (in een publiek toegankelijk document) en die stakeholders actief bij de onderneming betrekt. ${ }^{65}$ Ook dit zou de wetgever kunnen overnemen. Wel zou ik het ruim willen opvatten. Een fairtradeonderneming hoeft mijns inziens geen medezeggenschap toe te kennen aan de boeren in Afrika, maar kan zich wel openstellen voor een dialoog met (in Nederland actieve) ngo's die voor dergelijke stakeholders opkomen.

Voor grote maatschappelijke ondernemingen kan men wellicht een stap verder gaan door bijvoorbeeld aan stakeholders, vertegenwoordigd in een maatschappelijke raad, juist wel een zekere medezeggenschap toe te kennen. Dit zou bij een evaluatie van de nieuwe wet, vijf jaar na invoering, aan de orde kunnen komen.

\section{Handhaving van de BVm-regels}

Wil men dat het m-label een kwaliteitslabel wordt, dan zullen de toelatingscriteria en de eisen voor behoud van de status voldoende uitdagend en duidelijk moeten zijn. Duidelijke regels hoeven niet gedetailleerd en dichtgetimmerd te zijn. Juist in het ondernemingsrecht is gebleken dat men met open normen (zoals 'het belang van de vennootschap', 'behoorlijk bestuur' en 'ernstig verwijt') goed uit de voeten kan. Wel is het belangrijk die open normen zo te formuleren, dat zij voor ondernemers, stakeholders, adviseurs en rechters zeggingskracht hebben. Het EZK-voorstel voldoet mijns inziens niet in alle opzichten aan dit vereiste. Zo bieden de in paragraaf 5 besproken criteria rond het financieel beleid te weinig houvast.

\subsection{Georganiseerde reviews}

Naast de behoefte aan voldoende duidelijke regels is er de vraag wie deze gaat handhaven. Het EZK-voorstel voor toekenning van de $\mathrm{BVm}$-status organiseert slechts een magere toetsing vooraf (door de notaris) en geen reguliere toetsing 'gedurende de rit'. De notaris moet nagaan of het doel en de werkzaamheden, zoals opgeschreven door de ondernemer,

64. RSO-toelatingscriteria (versie 6 februari 2020), onder 'Principe 5: Transparantie - actief en toegankelijk'.

65. RSO-toelatingscriteria (versie 6 februari 2020), onder 'Principe 2: Stakeholders - bepaling en dialoog'. 
binnen het genoemde sectorenlijstje passen. Ter vergelijking: voor toelating tot het RSO wordt een zwaardere toetsing voorgeschreven (zie par. 3.3); bovendien worden eenmaal geregistreerde ondernemingen bij het RSO regelmatig onderzocht. De Stichting Code Sociale Ondernemingen, die het RSO beheert, heeft daarvoor een reviewteam opgetuigd dat de daadwerkelijke activiteiten beoordeelt.

Onder de wettelijke regeling kan de instantie die het m-label toekent dergelijke reviews doen. Deze kunnen betrekkelijk licht worden gehouden. Zo worden in België op regelmatige basis controles gehouden door de ambtenaren van de FOD Economie. ${ }^{66}$ Als alternatief kan wellicht worden gedacht aan een regeling zoals in Frankrijk, waar elke société à mission een apart comité de mission moet instellen en het naleven van de regels aan regelmatige accountantscontrole moet onderwerpen, ${ }^{67}$ maar dit zou de ondernemer verder op kosten jagen.

\subsection{Juridische actie achteraf}

Het EZK-voorstel leunt voor de handhaving vooral op stakeholders die met de BVm een dialoog willen aangaan en eventueel bereid zijn naar de rechter te stappen. Wanneer het BVmlabel wordt gevoerd door een ondernemer die daar formeel geen recht op heeft, mag iedere belanghebbende aan de rechter verzoeken een opheffing van de onrechtmatigheid te gebieden, aldus het voorstel. De inbreuk kan ook worden bestraft met een geldboete. ${ }^{68}$ Benadeelden kunnen in voorkomende gevallen ook acties wegens bedrog of misleidende handelspraktijken instellen. ${ }^{69}$

Daarnaast, zo memoreert het EZK-voorstel, biedt het geldende recht al de mogelijkheid om bij de rechter ontbinding van de vennootschap te vragen, indien de feitelijke werkzaamheden in ernstige mate in strijd zijn met het statutaire doel. Zoals vermeld in de parlementaire geschiedenis leent dit middel zich slechts voor spaarzame toepassing. ${ }^{70}$ Ontbinding is een paardenmiddel en daarom een ultimum remedium. Bovendien speelt bij de ontvankelijkheid van een ontbindingsverzoek een rol, aldus de Hoge Raad, 'in hoeverre de verzoeker door de uitkomst van de desbetreffende procedure zodanig in een eigen belang kan worden getroffen dat deze daarin behoort te mogen opkomen ter bescherming van dat belang, of in hoeverre deze anderszins zo nauw betrokken is of is geweest bij het onderwerp dat in de procedure wordt behandeld, dat daarin een belang is gelegen om in de procedure te

66. Aldus het overzicht 'erkenning als sociale onderneming' op www.economie.fgov.be.

67. Art. L. 210-10 Code de commerce. Zie ook J.M. de Jongh, Onderneming en maatschappij: naar een nieuw sociaal contract? De 'loi pacte' als voorbeeld, Ondernemingsrecht 2020/80.

68. EZK-voorstel 2021, p. 5, 6 en 9, verwijzend naar art. 5b, 6 en 7 Handelsnaamwet. Het betreft een geldboete van de tweede categorie; deze kent momenteel een maximum van EUR 4350.

69. EZK-voorstel 2021, p. 9, verwijzend naar art. 3:44 en 6:193c BW.

70. EZK-voorstel 2021, p. 9-10, verwijzend naar art. 2:21 lid 3 en 4 BW, en MvA II, Parl. Gesch. BW Boek 2 Inv. 1977, p. 1115; in dezelfde zin: Parl. Gesch. BW Inv. 3, 5 en 6 Aanpassing BW 1991, p. 197. verschijnen'. ${ }^{71}$ Of een (maatschappelijke) organisatie die de $\mathrm{BVm}$ bij de les wil houden en gepoogd heeft met deze in dialoog te gaan tot de kring van belanghebbenden behoort die met een ontbindingsverzoek ontvankelijk zijn, is onzeker. Al met al lijkt de mogelijkheid van een ontbindingsverzoek als handhavingsmiddel weinig effectief.

In het kader van de handhaving wijst het EZK-voorstel verder op de mogelijkheid voor belanghebbenden om excessieve uitkeringen aan te vechten, maar transparantie over de hoogte van uitkeringen is niet voorzien. Dit bemoeilijkt de mogelijkheid voor buitenstaanders om actie te ondernemen. Transparantie over het winst- en reservebeleid wordt wél voorzien (zie par. 5.1), maar dat is iets anders.

Het besluit tot vaststelling van een ernstig tekortschietend winst- en reservebeleid zal volgens het voorstel nietig zijn wegens strijd met de wet (art. 2:14 BW). Hetzelfde geldt voor een uitkeringsbesluit dat op een dergelijk gebrekkig winst- en reservebeleid is gebaseerd. ${ }^{72}$ Indien dit al juist is - nietigheid is geen gebruikelijke sanctie op gebrekkig beleid of daarop gebaseerde uitvoeringsbesluiten -, dan nog lijkt dit een vrij zwak handhavingsmiddel, aangezien het alleen bij extreme misstanden inzetbaar zou zijn. Wel zal het bestuur van de BVm bij onenigheid met de aandeelhouders enige formele bevoegdheden hebben om verantwoorde besluiten af te dwingen (zie ook par. 5.2), maar binnen veel vennootschappen zijn de bestuurders niet onafhankelijk van de aandeelhouders. In een dergelijke situatie is de slagkracht van het bestuur beperkt. Juridische mogelijkheden voor derden om misstanden aan te kaarten zijn dus niet onbelangrijk.

Bij het handhavingsarsenaal noemt het EZK-voorstel ook nog de mogelijkheid om wanneer de BVm investeringen doet die niet bij het maatschappelijk doel passen, de nietigheid van het investeringsbesluit in te roepen of een beroep op doeloverschrijding te doen. ${ }^{73}$ Hierbij geldt dat een investeringsbesluit niet snel nietig zal zijn, eerder vernietigbaar. ${ }^{74}$ Afgezien van de rechtspersoon zelf moet men een 'redelijk belang' hebben om bij de rechter om vernietiging te kunnen vragen. ${ }^{75}$ Dit roept soortgelijke vragen over ontvankelijkheid op als zojuist bij het ontbindingsverzoek genoemd. Bovendien maakt nietigheid of vernietiging van het onderliggende besluit de daarop gebaseerde investering nog niet ongeldig. De investering zelf kan alleen in extreme gevallen met een beroep op doeloverschrijding worden aangetast en die weg staat alleen voor de vennootschap zelf open, ${ }^{76}$ niet voor anderen. Ook deze handhavingsroutes

71. HR 12 oktober 2018, ECLI:NL:HR:2018:1900 (Stichting ANV Fondsen).

72. EZK-voorstel 2021, p. 16

73. EZK-voorstel 2021, p. 19, verwijzend naar art. 2:7 en 2:14 BW.

74. Voor een fraaie beschouwing waarin investeringsbesluiten mijns inziens terecht als 'besluiten' in de zin van art. 2:14 en 2:15 BW worden opgevat, zie A.F. Verdam, Terug naar het begrip 'besluit' zoals het is bedoeld, WPNR 2021, afl. 7322, p. 337-346.

75. Art. 2:15 lid $3 \mathrm{BW}$.

76. Art. 2:7 BW 


\section{Maandblad}

Ondernemingsrecht

zullen bij het op de rails houden van de vennootschap door derden dus geen hoofdrol spelen.

Dit brengt mij bij de passage in het EZK-voorstel die de mogelijkheid biedt voor 'een stichting of vereniging die collectieve belangen van anderen behartigt' om een enquêteprocedure te starten. De enquête zou worden ingesteld 'naar het beleid en de gang van zaken van een $\mathrm{BVm}$ in relatie tot het maatschappelijk belang dat in de statuten van de BVm is neergelegd'. Voorwaarde is dat een dergelijke stichting of vereniging statutair een of meer maatschappelijke belangen behartigt van dezelfde categorie als het BVm-doel. Dit is een aanvulling op de reeds uit Boek $2 \mathrm{BW}$ voortvloeiende mogelijkheden tot het indienen van een enquêteverzoek. ${ }^{77}$ Voor toewijzing van een enquêteverzoek zal, op grond van de al bestaande regels, moeten blijken 'van gegronde redenen om aan een juist beleid of juiste gang van zaken te twijfelen' ${ }^{78}$

\subsection{Waakhonden en trendsetters}

Dit laatste voorstel, rond het enquêterecht, lijkt een betrekkelijk krachtig instrument te kunnen zijn, indien er voldoende kwalificerende stichtingen en verenigingen zijn die daadwerkelijk bereid zullen zijn de vinger aan de pols te houden. Actiebereidheid van private waakhonden kan een uitholling van het begrip 'maatschappelijke onderneming' helpen beperken. Het moet evenwel niet zo zijn dat men door het oprichten van een stichting met een passend statutair doel eenvoudig ontvankelijk wordt in een enquêteverzoek. De ontvankelijkheid zou beperkt moeten blijven tot verenigingen en stichtingen die daarop, gezien het stakeholderbeleid dat van de maatschappelijke onderneming verwacht mag worden, redelijkerwijs aanspraak kunnen maken. Tegelijkertijd lijkt de kring van enquêtebevoegden in het voorstel onnodig krap bemeten door de eis dat maatschappelijke belangen worden behartigd 'van dezelfde categorie als het BVm-doel'. Organisaties die aan maatschappelijk ondernemen in het algemeen willen bijdragen, zoals de Stichting Code Sociale Ondernemingen, zouden eveneens een enquêteverzoek moeten kunnen doen.

Verder valt te overwegen om elke instantie met enquêtebevoegdheid bij de betrokken BVm tevens als 'belanghebbende' aan te merken in de zin van andere rechtsmiddelen. Hierbij kan worden gedacht aan het al besproken verzoek tot ontbinding van de vennootschap en het verzoek tot vernietiging van een vennootschapsbesluit (zoals het besluit tot het doen of goedkeuren van een bepaalde uitkering). ${ }^{79}$

Maar procederen (en het instellen van een enquête) is juridificerend en duur. Rechtszaken komen altijd achteraf, in een slechte sfeer, nadat de ruzie of gepercipieerde misstand is ontstaan. Mogelijkheden tot procederen doen daarom niet af aan het belang van screening, transparantie en dialoog (zie

\footnotetext{
77. EZK-voorstel 2021, p. 26. Het enquêterecht is geregeld in art. 2:344 e.v. BW.

78. Art. 2:350 lid $1 \mathrm{BW}$.

79. Art. $2: 15$ en $2: 21 \mathrm{BW}$.
}

par. 3.3, 6 en 7.1). Partijen met enquêtebevoegdheid kunnen worden geaccommodeerd in het aangaan van een dialoog door de weigering van een $\mathrm{BVm}$ om bepaalde relevante informatie met een dergelijke partij te delen al snel aan te merken als een 'gegronde reden om aan een juiste gang van zaken te twijfelen'.

Geregelde reviews, als men die organiseert, kunnen in een positieve sfeer plaatsvinden. Mensen kunnen daar energie en inspiratie uit putten. Er kan expertise worden opgebouwd waar ondernemingen, de overheid en de samenleving van kunnen profiteren. De instantie die het m-label toekent, zou ook met een functie als de Monitoringcommissie Corporate Governance kunnen worden belast: het inventariseren van geboekte resultaten en het helpen sturen van verdere ontwikkelingen. ${ }^{80}$

\section{Keuze voor en beëindiging van de BVm-status} Volgens het EZK-voorstel moeten de statuten van een BVm een 'doel' en 'voorwerp van werkzaamheid' benoemen die binnen het besproken sectorenlijstje vallen. Ook moeten de statuten een eventueel batig liquidatiesaldo bestemmen voor een andere $\mathrm{BVm}$ of andere rechtspersoon met een ideëel of sociaal doel. ${ }^{81}$ Dergelijke statutaire bepalingen maken van een $\mathrm{BV}$ nog geen $\mathrm{BVm}$.

\subsection{De keuze voor het BVm-label}

De keuze voor het BVm-label (en daarmee onderwerping aan de BVm-vereisten) wordt volgens het voorstel in een aparte notariële akte vastgelegd. Binnen de vennootschap wordt die keuze door het bestuur gemaakt. ${ }^{82}$

Dat het bestuur (en niet de algemene vergadering) de keuze voor het m-label makkt, is prima, maar dit zal toch niet zonder instemming van de algemene vergadering kunnen. Alleen al de beperkingen die de $\mathrm{BVm}$-status voor het doen van uitkeringen meebrengt (zie par. 5), maken instemming van de aandeelhouders onontkoombaar. Als dus sowieso een aandeelhoudersbesluit vereist is, kan de keuze mijns inziens maar beter in de statuten worden vastgelegd. Dat is wel zo overzichtelijk. De statuten vormen het document bij uitstek om alle directe stakeholders (waaronder zittende en toekomstige bestuurders en aandeelhouders) aan langetermijnafspraken te binden. De reden voor een aparte notariële akte ontgaat mij.

Het komt mij gewenst voor om als eis te stellen dat alle aandeelhouders met een keuze voor de BVm-status instemmen. Hun actieve instemming kan ertoe bijdragen dat aan het $\mathrm{m}$-label daadwerkelijk inhoud wordt gegeven. Als alle aandeelhouders de BVm-status willen, kan elke aandeelhouder een bondgenoot zijn in het op koers houden van de vennootschap. Algemene instemming beperkt ook de juridische mogelijkheid voor individuele aandeelhouders om zich later te beklagen over beslissingen die vanuit de BVm-status juist verantwoord

80. Zie www.mccg.nl.

81. EZK-voorstel 2021, p. 6, 7 en 25. Zie par. 3.2 en 5.1.

82. EZK-voorstel 2021, p. 2-5. 
zijn, zoals bepaalde strategische beslissingen en uitkeringsbeperkingen.

\subsection{Beëindiging van de BVm-status}

Ook vrijwillige beëindiging van de BVm-status geschiedt volgens het EZK-voorstel bij bestuursbesluit. Het beëindigingsbesluit moet worden gedeponeerd bij het handelsregister en die deponering moet worden aangekondigd in een landelijk verspreid dagblad. Vervolgens hebben belanghebbenden een maand de tijd om bij de rechtbank eventueel verzet aan te tekenen tegen het beëindigingsbesluit. De rechtbank wijst het verzet toe 'indien er gegronde redenen zijn om aan te nemen dat het besluit strijdig is met het belang van voortgezette toepasselijkheid' van de BVm-regeling. Het beëindigingsbesluit wordt niet van kracht zolang verzet kan worden aangetekend en de eventuele rechtbankprocedure loopt. ${ }^{83}$ Voor de situatie waarin wordt voorgesteld de $\mathrm{BVm}$ weg te fuseren in een vennootschap die geen $\mathrm{BVm}$ is, biedt het EZK-voorstel eenzelfde verzetsprocedure (als onderdeel van de crediteurenverzetsregeling die bij juridische fusie al bestaat). ${ }^{84}$

Deze voorstellen verdienen enige aanscherping. Vrijwillige beëindiging van de BVm-status is ingrijpend. Ook aan de aandeelhouders komt daarbij een verantwoordelijkheid en een bevoegdheid toe. Wordt de keuze voor de BVm-status in de statuten vastgelegd, zoals ik voorsta, dan is voor beëindiging daarvan een statutenwijziging vereist. Instemming door de algemene vergadering is dan een vanzelfsprekend vereiste. Om te voorkomen dat lichtvaardig voor beëindiging wordt gekozen, kan men voor het beëindigingsbesluit een unaniem aandeelhoudersbesluit voorschrijven. Verder valt te overwegen om elke instantie met enquêtebevoegdheid bij de betrokken BVm (zie par. 7.3) tevens als 'belanghebbende' in de zin van de verzetsprocedure aan te merken.

Verder is mijns inziens nog behoefte aan een procedure waarin het $m$-label kan worden afgepakt van de vennootschap die zich niet aan de regels houdt. Dit is dan een alternatief voor het zware ontbindingsverzoek dat in paragraaf 7.2 aan de orde kwam. Het begrip 'belanghebbende' bij het verzoek tot gedwongen beëindiging van de BVm-status mag wat mij betreft net zo ruim zijn als zojuist bij de verzetsprocedure bepleit. In de door mij voorgestelde opzet brengt de gedwongen beëindiging van de m-status een statutenwijziging mee. Voor gevallen waarin het doelgebonden karakter van het vennootschapsvermogen daar dringend om vraagt, kan men aan de gedwongen beëindiging van de $\mathrm{m}$-status ook een verplichte (al dan niet partiële) vermogensoverdracht verbinden.

\section{Conclusie}

Samenvattend: het initiatief voor een wettelijke verankering van de maatschappelijke onderneming verdient steun. De eerste stappen die EZK op dit nieuwe terrein heeft gezet, waar-

83. EZK-voorstel 2021, p. 23.

84. EZK-voorstel 2021, p. 20, met verwijzing naar art. 2:314 BW. Een dergelijke regeling is ook voorzien bij juridische splitsing. deer ik zeer. Wel zie ik nog ruimte voor verbetering. Het voorstel verdient enige aanscherping om er, zonder afbreuk aan het 'gelijk speelveld'-beginsel, een reële bijdrage aan de marktontwikkeling van maatschappelijke ondernemingen van te maken.

De doelgroep die het voorstel op het oog heeft, kan duidelijker in beeld worden gebracht (kwalitatief en kwantitatief). $\mathrm{Nu}$ lijkt de doelgroep nogal ruim (het formele sectorenlijstje) en tegelijkertijd wat smal (geen rechtsvormen buiten de BV; geen sectoren buiten het lijstje). Voor de behoefte waarin de wettelijke verankering beoogt te voorzien (onder meer hulpmiddel voor impactfinanciers en voor overheden en anderen die aan 'buy social' willen doen), lijken iets uitdagender criteria en een multirechtsvormlabel aantrekkelijker. Misschien zijn er goede (praktische) redenen om het m-label tot de BV te beperken, althans in een eerste experimentele fase, maar de argumenten in het EZK-voorstel zijn daartoe ontoereikend.

Bij de baten voor ondernemers verdient nader onderzoek (1) of aan de BVm de mogelijkheid kan worden geboden de anbi-status te verwerven, en (2) of bij de BVm behoefte bestaat aan meer flexibiliteit binnen de Boek 2 BW-regels. Dit laatste zou gunstig kunnen zijn bij het opzetten van steward ownership-structuren. Deze mogelijkheden zouden bij een evaluatie vijf jaar na invoering van het m-label kunnen worden betrokken.

Verder is wenselijk dat de BVm-regels het gehele financiële beleid betreffen, niet alleen de winstbestemming. Naast een gerichtheid op het maatschappelijk doel kan een algemene matigheidsnorm van pas komen. Matigheid bij het stellen van winstdoelen, het doen van uitkeringen, het toekennen van (bestuurs)beloningen, et cetera. Tevens mag worden gevraagd dat een BVm zich aan hoge MVO-standaarden committeert. De transparantievoorschriften kunnen eveneens scherper dan in het EZK-voorstel voorzien, door publicatie van relevante informatie op de website van de BVm voor te schrijven, toegang tot die websites via een openbaar register te regelen, en iets strengere eisen te stellen aan de inhoud van de openbaar te maken informatie.

Bij het voorgestelde handhavingsinstrumentarium ligt het zwaartepunt van het EZK-voorstel bij een enquêtebevoegdheid voor kwalificerende stichtingen en verenigingen. Instanties die voor een enquêteverzoek kwalificeren, mogen wat mij betreft tevens worden aangemerkt als 'belanghebbenden' in de zin van andere rechtsmiddelen (zoals verzoeken tot vernietiging van besluiten binnen de vennootschap). $\mathrm{Zij}$ mogen ook een steuntje in de rug krijgen met bijzondere informatierechten. Dit kan een goede dialoog helpen bevorderen en daardoor de kans op vervelende rechtszaken helpen verkleinen.

Om het groenwasrisico te beperken lijkt het verder nuttig om inhoudelijke beoordelingen te organiseren, zowel voorafgaand aan de wettelijke erkenning van een maatschappelijke onder- 


\section{Maandblad}

Ondernemingsrecht

neming als geregeld nadien. EZK zou dit in eigen beheer kunnen nemen, maar het ook elders kunnen onderbrengen. De keuze van een vennootschap om de $\mathrm{BVm}$-status te verwerven, of deze vrijwillig te beëindigen, dient mijns inziens aan de instemming van alle aandeelhouders te worden onderworpen. Ten slotte bepleit ik een procedure om de rechtspersoon die zich niet aan de regels houdt het m-label te kunnen afpakken. 